\title{
A Child Psychiatry Clinical Sample of Adolescents' Covid-19 Perception and Compliance with Measures
}

\section{Bir Çocuk Psikiyatrisi Klinik Örnekleminde Ergenlerin Covid-19 Algısı ve Tedbirlere Uyumu}

\author{
Ömer BAŞAY ${ }^{1}$ (D) , Bürge KABUKÇU BAŞAY ${ }^{1}$ (D) , Funda ÖZTÜRK ${ }^{2}$ (D) \\ ${ }^{1}$ Pamukkale University, Faculty of Medicine, Department of Child and Adolescent Psychiatry, Denizli, TURKEY \\ ${ }^{2}$ Beyhekim Training and Research Hospital, Department of Child and Adolescent Psychiatry, Konya,TURKEY
}

\section{Abstract}

Background: Our study aimed to assess the Covid-19 perception of adolescents who were admitted to child psychiatry outpatients and their compliance with preventive measures. Also, we evaluated whether there was an increase in the psychological distress of the participants during the pandemic.

Materials and Methods: A study invitation and a questionnaire link were sent to the parents of 12-18 years old adolescents who applied to child and adolescent psychiatry outpatients for any reason in the three months before the Covid-19 pandemic onset. Between April-May 2020, 32 girls and 21 boys filled the online survey. The survey included the Childhood Depression Inventory and The Screen for Child Anxiety Related Disorders and questions for obtaining sociodemographic data, questions about adolescents' perception of Covid-19 infection, and questions asking whether there was an increase in their psychological distress.

Results: \% of the adolescents perceived Covid- 19 as a health threat, $60.4 \%$ reported that they were obeying Covid19 preventive measures. $30.4 \%$ were using a mask, $90.6 \%$ covered their mouth and nose while sneezing, and $94.3 \%$ were paying attention to social distance. While the use of immune system support products was statistically significantly higher in female adolescents $(x 2=6.359 ; p=0.017)$, there was no statistical difference in other health behaviors. $32.1 \%$ of the adolescents reported an increase in complaints that caused them to refer to child psychiatry outpatients. The diagnostic status or the anxiety or depression level of the adolescents were not found to influence their compliance.

Conclusions: The study results showed the adolescents who had child psychiatry outpatient referral history in the pre-pandemic period and had higher levels of psychiatric complaints than the general community complied with Covid-19 precautions moderate-good level. Also, about a third of them experienced an increase in their application complaints.

Key Words: Pandemic, Preventive measures, Precautions, Psychological distress, Psychiatric disorder

öz.

Amaç: Çalışmamız, çocuk psikiyatrisi polikliniğine başvuran ergenlerin Covid-19 algılarını ve önleyici tedbirlere uyumlarını değerlendirmeyi amaçlamaktadır. Ayrıca pandemi sırasında katılımcıların psikolojik sıkıntılarında artış olup olmadığı değerlendirilmiştir.

Materyal ve Metod: Covid-19 pandemi başlangııından önceki 3 aylık dönemde herhangi bir nedenle çocuk ve ergen psikiyatri polikliniğine başvuran 12-18 yaş ergenlerin ebeveynlerine çalışma davetiyesi ve anket linki gönderilmiştir. Nisan-Mayıs 2020 arasında 32 kız ve 21 erkek çevrimiçi anketi doldurmuştur. Ankette Çocukluk Depresyon Envanteri ve Çocukluk Çağı Kaygı Bozuklukları Özbildirim Ölçeği Çocuk Formu ile sosyodemografik veriler elde edilmesine yönelik sorular, ergenlerin Covid-19 enfeksiyonu algısına ilişkin sorular ve psikolojik sıkıntılarında artış olup olmadığına dair sorular yer almaktadır.

Bulgular: Ergenlerin \% 66'sı Covid-19'u sağlık tehdidi olarak algıladı, \%60,4'ü Covid-19 önleyici tedbirlere uyduğunu bildirmiştir. Ergenlerin \%30,4'ü maske kullanıyor, \%90,6'sı hapşıırken ağzını ve burnunu kapatıyor, \%94,3'ü sosyal mesafeye dikkat ediyordu. Kız ergenlerde bağışıklık sistemi destek ürünleri kullanımı istatistiksel olarak anlamlı düzeyde yüksek bulunurken $(x 2=6,359 ; p=0,017)$, diğer sağılık davranışları açısından fark yoktu. Ergenlerin\% $32,1^{\prime} i$ çocuk psikiyatrisi polikliniklerine başvurmalarına neden olan şikayetlerinde artı̧̧ olduğunu bildirmiştir. Ergenlerin tanısal durumlarının ve anksiyete veya depresyon düzeylerinin uyumlarını etkilemediği görülmüştür.

Sonuç: Çalışma sonuçları, pandemi öncesi dönemde çocuk psikiyatrisi poliklinik başvuru öyküsü olan ve genel topluma göre daha yüksek düzeyde psikiyatrik yakınmaları olan ergenlerin orta-iyi düzeyde Covid-19 önlemlerine uyduğunu göstermiştir. Ayrıca, yaklaşık üçte biri başvuru şikayetlerinde artış yaşamıştır.

Anahtar kelimeler: Pandemi, Önleyici tedbirler, Koruyucu önlemler, Psikolojik sıkıntı, Psikiyatrik bozukluk
Sorumlu Yazar/Corresponding Author

Dr. Ömer BAŞAY

Pamukkale Üniversitesi, Tıp Fakültesi, Çocuk ve Ergen Ruh Sağlığı ve Hastalıkları Anabilim Dalı, Kınıklı, Denizli, TÜRKIYE, 20070

E-mail: omer_basay@yahoo.com

Geliş tarihi / Received: 01.03.2021

Kabul tarihi / Accepted: 28.05.2021

DOI: $10.35440 /$ hutfd. 888635 


\section{Introduction}

The Coronavirus infection 2019 (Covid-19) has spread to the whole world after announcing the first case in ChinaWuhan in December 2019 (1). World Health Organization declared the outbreak as a global pandemic on March 11, 2020 , and on the same day, the first case was reported in Turkey (2,3). Covid-19 virus contaminates easily and causes an infection which transmits rapidly by airborne and close contact (4). The unavailability of an effective treatment and the high morbidity and mortality rates of the disease implemented preventive measures essential (5). Together with the World Health Organization, Turkey's Ministry of Health suggested preventive measures such as providing hand hygiene, adhering to social distance rules, and using personal protective equipment (6).

Adolescence is a vulnerable period with its own developmental characteristics (7). The changing mental structure and brain biochemistry during adolescence lead to changes in the adolescent's perception of risk, causing him/her to think that he is protected from harm. For this reason, adolescents tend to be prone to risky behavior (8). Also, autonomy is essential for an adolescent; thus, increased conflicts with authority and difficulty in following rules can be expected during this period (9). Therefore, it may be more difficult for young people to perceive the hazard caused by Covid-19 infection and comply with preventive measures compared to adults. Accordingly, literature research has revealed some findings that support that adolescents and young adults may have difficulty in compliance with precautions $(10,11)$. Moreover, the Covid-19 disease is often asymptomatic in children and adolescents, but they transmit the infection to others, facilitating the disease's spread (12). When we consider all of these collectively, it becomes crucial to understand adolescents' Covid-19 pandemic perceptions and their compliance with the measures.

Also, adolescence is a process that lays the groundwork for the development of psychopathology (13). Thus, the prevalence of mental disorders increases in this period $(14,15)$. It is evident that the Covid-19 pandemic and related constrictions in daily life impacted the adolescents' psychological wellness adversely (16). Besides, being under mental stress or having a psychiatric illness can affect the coping and adaptation skills under challenging times, or stressful life events may increase the current psychological distress (16-21). Therefore, perception of the Covid-19 pandemic and the psychological effects of a pandemic on adolescents who have been previously admitted to the child psychiatry outpatient clinic for any reason may differ from that of general society, and the effects of stressful life events may vary on girls and boys $(22,23)$. For these reasons, while investigating the Covid-19 related thoughts and attitudes of the adolescents and the pandemic's psychological effects, it is beneficial to research clinical samples and assess gender effects to develop more appropriate approaches and treatment strategies for them.
Our study aimed to investigate the Covid-19 perception and the preventive measure compliance of adolescents who applied to child and adolescent psychiatry outpatients for any reason in the three months-time before the onset of the pandemic in Turkey. We also assessed whether the participants experienced increments in their previous psychological distress concerning pandemic and evaluated these parameters' variation according to gender. Another purpose of the study was to research whether the adolescents' pandemic-related psychological influence and compliance differed according to the adolescent's diagnosis.

\section{Materials and Methods}

The research was planned as a cross-sectional study. Adolescents between the ages of 12-18 applied to Pamukkale University Medical Faculty Child and Adolescent Psychiatry outpatients for any reason in the three months before the onset of the Covid-19 pandemic (March 2020) constituted the study universe. We sent an online study invitation and a questionnaire link via mobile phone to the parents of those adolescents who have an accessible phone number in the system records. The invitation included information about the name, purpose, and the authors of the study. In the link, we stated that the research was based on volunteering, and the data obtained would be used for scientific purposes following the privacy policy of personal data. We sought the parents' and adolescents' consent for the study, and the participants completed the online questionnaire. The study's exclusion criteria were illiteracy of the parent and the adolescent's mental illness that would interfere with understanding and filling out the forms (autism spectrum disorder, mental retardation, acute psychotic attack, acute manic attack). It took about 15-20 minutes to complete the online survey. The adolescents filled out the forms themselves. Only the participants who filled the study questions completely were included in the study. Eighty random adolescents, who were evaluated in the child and adolescent psychiatry outpatients for any reason in the last three months, were invited to participate in the study. Twelve people did not return to the invitation, ten people did not approve of participation in the study, and five people did not fully complete the questionnaire. Fifty-three adolescents who met the inclusion criteria formed the study sample. We obtained information about the participants' follow-up diagnoses from the system records of the child psychiatry outpatients. Study data were collected in the first months of the Covid-19 pandemic, in April-May 2020. Before the study, Pamukkale University Ethics Committee (Date: 16/04/2020 No: 60116787-020/26616) and the Turkish Republic Ministry of Health approved the study. The study forms are explained below.

Sociodemographic Data Form: The study authors formed it to inquire data about the age, gender, school grade of 
the adolescent, the educational status of the parents, and the parents' profession.

Coronavirus Perception Form: This scale was inspired by the questions posed for SARS perception in the study conducted to examine Chinese adolescents' health behaviors during SARS infection (24). Similar items were asked for the Covid-19 disease. The form included questions that asked the adolescent's compliance with the measures taken to protect himself/herself from the Covid-19 pandemic and investigated his/her perception of the Covid-19 pandemic. In this section, questions asked whether the adolescent's psychological distress increased during the pandemic process compared to the pre-pandemic period.

The Children's Depression Inventory (CDI): It is a 27-item scale developed by Kovacs and can be applied to children and adolescents aged between 6 and 17 (25). Each item gets 0,1 , or 2 points according to the severity of the symptom. The highest possible score is 54 . The cut-off score of the scale is suggested as 19. The Turkish validity and reliability study of CDI was conducted by Öy (26).

Screen for Child Anxiety Related Emotional Disorders (SCARED)- child form: Birmaher et al. developed The SCARED with the aim of screening childhood anxiety disorders (27). Karaceylan conducted its Turkish validity and reliability study (28). The scale consists of 41 items, and each item is scored between 0-2 points on a 3-point Likert scale. The maximum score that can be obtained from the scale is 82. A score of 25 and above in SCARED is considered to be a warning for anxiety disorder.

We analyzed the data with SPSS software version 15.0 (SPSS INC, Chicago, Illinois).

Continuous variables are defined as mean \pm standard deviation (SD), and categorical variables are expressed as numbers ( $\mathrm{n}$ ) and percentages (\%). Chi-square test analyzed the differences between categorical variables, and MannWhitney-U Test examined the differences between nonnormally distributing numeric variables between the two groups. Statistical significance is accepted if $p<0.05$.

\section{Results}

Fifty-three adolescents, 60.4\% ( $n=32)$ girls and 39\% ( $n=21)$ boys, participated in the study. The mean age of the participants was $15.86 \pm 1.01$ years old. $37.7 \%(n=20)$ of the participants were attending secondary school $\left(5^{\text {th }}\right.$ to $8^{\text {th }}$ classes), while $60.4 \%(n=32)$ were attending high school $\left(9^{\text {th }}\right.$ to $12^{\text {th }}$ classes). One case $(1.9 \%)$ was not attending school. The primary diagnoses of the participants were as follows: $54.7 \%(n=29)$ had attention deficit hyperactivity disorder (ADHD), 28.3\% ( $n=15)$ had anxiety disorder, $11.3 \%(n=6)$ had depression and $5.7 \%(n=3)$ had obsessivecompulsive disorder diagnosis. Among the ADHD diagnosed participants six cases had comorbid oppositional defiant disorder and/or conduct disorder diagnoses. The other participants had no comorbid diagnosis. Table 1 presents the sociodemographic characteristics of the participants.
Table 1. Sociodemographic characteristics of the participants

\begin{tabular}{llc}
\hline & & $\begin{array}{c}\text { Mean } \pm \text { SD / n } \\
(\%)\end{array}$ \\
\hline Age & & $15.86 \pm 1.01$ \\
\hline Gender & Girls & $32(\% 60.4)$ \\
& Boys & $21(\% 39.6)$ \\
\hline Mother's education level & & \\
& Primary education & $18(\% 34.0)$ \\
& High school & $8(\% 15.1)$ \\
& University & $27(\% 50.9)$ \\
\hline Father's education level & & \\
& Primary education & $16(\% 30.2)$ \\
& High school & $12(\% 22.6)$ \\
& University & $25(\% 47.2)$ \\
\hline Mother's profession & & \\
& Housewife & $27(\% 50.9)$ \\
& Officer & $20(\% 37.7)$ \\
& Worker & $6(\% 11.3)$ \\
\hline Father's profession & & \\
& Officer & $22(\% 41.5)$ \\
& Worker & $18(\% 34.0)$ \\
& Craft/shopkeeper & $13(\% 24.5)$ \\
\hline
\end{tabular}

\section{Adolescents' Covid-19 perception, compliance to Covid- 19 preventive measures, and their attitudes}

When we assessed the responses concerning the Covid-19 perception and thoughts about the pandemic, we found that $66 \%$ of the adolescents perceived Covid-19 infection as a severe health threat $(n=35), 32.1 \%(n=17)$ a partial health threat. In comparison, $1.9 \%(n=1)$ stated they did not perceive the infection as a health threat (Figure 1). 94.3\% $(n=50)$ of respondents were thinking that they were adequately informed about Covid-19, and $92.5 \%(n=49)$ were thinking that the preventive measure will be effective in the control of the spread of the virus (Table 2).

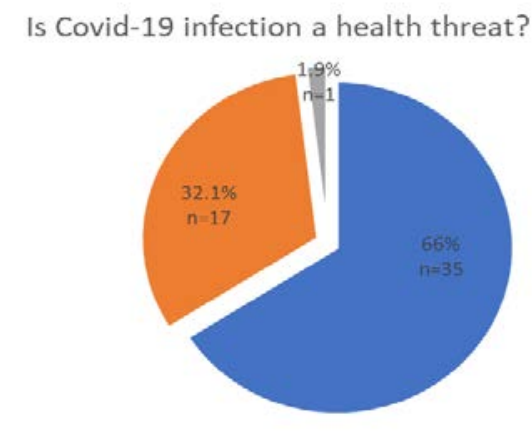

- a serios health threat = a partial health threat = not a health threat

Figure 1. The adolescents' perception of Covid-19

We evaluated the adolescents' compliance to preventive measures and their attitudes. Accordingly, 60.4\% ( $n=32)$ stated that they were adhering to all warnings about the covid-19 pandemic, and 39.6\% $(n=21)$ were not. Table 2 shows the adolescents' thoughts and attitudes about the Covid-19 pandemic. A statistically significant difference was found between boys and girls in the use of supportive products, that girls were using supportive products more 
than boys $\left(90.6 \%\right.$ for girls, $61,9 \%$ for boys) $\left(x^{2}=6.359\right.$; $p=0.017)$. The other parameters were not statistically significantly different between girls and boys ( $p>0.05$ ) (Table 2 ). Figures 2 and 3 present the adolescents' worries about the transmission of the infection to themselves and to their relatives.
No statistically significant difference was found between girls and boys in terms of concern about getting infected with Covid-19 ( $\left.x^{2}=3.257 ; p=0.354\right)$. Similarly, there was no statistically significant difference between girls and boys regarding the Covid-19 transmission to relatives $\left(x^{2}=2.690\right.$; $p=0.442$ ).

Table 2. Participants' thoughts and attitudes during the Covid-19 pandemic

\begin{tabular}{|c|c|c|c|c|c|c|c|}
\hline & \multicolumn{2}{|c|}{ Girls } & \multicolumn{2}{|c|}{ Boys } & \multicolumn{2}{|c|}{ Total } & \multirow[b]{2}{*}{$\mathrm{p}$} \\
\hline & $\mathrm{n}$ & $\%$ & $\mathrm{n}$ & $\%$ & $\mathrm{n}$ & $\%$ & \\
\hline \multicolumn{8}{|l|}{ Thoughts } \\
\hline I was well informed about Covid-19 (yes) & 30 & 93.8 & 20 & 95.2 & 50 & 94.3 & 0,999 \\
\hline $\begin{array}{l}\text { The preventive measures recommended by the Ministry of Health will be ef- } \\
\text { fective in preventing the spread of the Covid-19 (yes) }\end{array}$ & 29 & 90.6 & 20 & 95.2 & 49 & 92.5 & 0,928 \\
\hline \multicolumn{8}{|l|}{ Adherence to the measures } \\
\hline $\begin{array}{l}\text { I adhere to the measures (preventive rules and precautions) about the Covid- } \\
19 \text { (yes) }\end{array}$ & 18 & 56.3 & 14 & 66.7 & 32 & 60.4 & 0,448 \\
\hline \multicolumn{8}{|l|}{ Hand washing } \\
\hline 1-5 times & 5 & 15.6 & 5 & 23.8 & 10 & 18.9 & \\
\hline 6-10 times & 15 & 46.9 & 11 & 52.4 & 26 & 49.1 & 0,530 \\
\hline More than 11 times & 12 & 37.5 & 5 & 23.8 & 17 & 32.1 & \\
\hline I use mask every time I go out & 12 & 37.5 & 6 & 28.6 & 18 & 34.0 & 0.708 \\
\hline I close my mouth and nose when sneezing / coughing & 31 & 96.9 & 17 & 81.0 & 48 & 90.6 & 0,074 \\
\hline I use hand disinfectant & 17 & 53.1 & 10 & 47.6 & 27 & 50.9 & 0,695 \\
\hline I ventilate my environment & 27 & 84.4 & 17 & 81.0 & 44 & 83.0 & 0,747 \\
\hline I pay attention to social distance rule & 32 & 100 & 18 & 85.7 & 50 & 94.3 & 0,057 \\
\hline \multicolumn{8}{|l|}{ To strengthen my immune system... } \\
\hline I eat regularly & 20 & 62.5 & 14 & 66.7 & 34 & 64.2 & 0.757 \\
\hline I use supportive products (vitamin or mineral pills, herbal medicine etc.) & 29 & 90.6 & 13 & 61.9 & 42 & 79.2 & $0,017^{*}$ \\
\hline I sleep regularly & 22 & 68.8 & 13 & 61.9 & 35 & 66.0 & 0,827 \\
\hline
\end{tabular}

*Statistically significant difference was obtained at $p<0.05$ level (Fisher exact test)

\section{Findings concerning the psychological distress and diag- nosis of adolescents}

The mean total SCARED score was found to be $32.62 \pm 15.35(\min =2, \max =71)$. While $38(71.7 \%)$ adolescents had a score equal to or above the cut-off point of 25 , 15 (28.3\%) scored 24 and below. The mean total CDI score was $16.09 \pm 7.93$ ( $\min =2, \max =32) .20(37.7 \%)$ participants received a value equal and above the cut-off point of 19 , while 33 (62.3\%) had a score below the cut-off. When the participants were asked about their mental status compared to the period before the Covid-19 pandemic, $41.5 \%$ $(n=22)$ stated that they were more anxious than before, $43.4 \%(n=23)$ were more unhappy and sad, $49.1 \%(n=36)$ were more irritable and nervous and $37.7 \%(n=20)$ were more inattentive and had more concentration problems. The proportion of those who had increased sleep problems was $54.7 \%(n=29)$, and the proportion of those who reported appetite changes was $58.5 \%(n=31)$.
Thirty-two percent $(n=17)$ of the participants stated an increase in the severity of the complaints that caused them

to refer to child psychiatry outpatients. There was no statistically significant difference in terms of these variables evaluated between girls and boys ( $p>0.05$ ) (Table 3 ).

We also wondered whether the adolescent's diagnosis impacted the adolescent's compliance to preventive measures and on the pandemic-related psychological distress aggravation. With this aim, we created two groups. The first group was externalizing disorder group composing of the adolescents with ADHD diagnosis $(n=29)$. The second group was the internalizing disorder group comprising adolescents with anxiety, depressive, and obsessive-compulsive disorder diagnoses $(n=24)$. Accordingly, we found no statistically significant difference in Covid-19 precautions' compliance $\left(x^{2}=0.088, p=0.774\right)$ and aggravation of application complaint $\left(x^{2}=1.852, p=0.174\right)$ according to the diagnostic group of the adolescents.

Finally, we analyzed the impact of anxiety and depression 
scores on some selected parameters. Table 4 shows the results.

Table 3. The psychological distress experienced by the participants compared to the period before the Covid-19 pandemic

\begin{tabular}{|c|c|c|c|c|c|c|c|}
\hline & \multicolumn{2}{|c|}{ Girls } & \multicolumn{2}{|c|}{ Boys } & \multicolumn{2}{|c|}{ Total } & \multirow[b]{2}{*}{$\mathbf{p}$} \\
\hline & $\mathbf{n}$ & $\%$ & $\mathbf{n}$ & $\%$ & $\mathbf{n}$ & $\%$ & \\
\hline I feel more anxious than before (Yes) & 15 & 46.9 & 7 & 33.3 & 22 & 41.5 & 0,488 \\
\hline I feel more sad and unhappy compared to before (yes) & 16 & 50.0 & 7 & 33.3 & 23 & 43.4 & 0,361 \\
\hline I feel more irritable and nervous than before (yes) & 18 & 56.3 & 8 & 38.1 & 36 & 49.1 & 0,311 \\
\hline $\begin{array}{l}\text { I live concentration problems and inattentiveness com- } \\
\text { pared to before (yes) }\end{array}$ & 15 & 46.9 & 5 & 23.8 & 20 & 37.7 & 0,160 \\
\hline I live sleep problems compared to before (yes) & 20 & 62.5 & 9 & 42.9 & 29 & 54.7 & 0,261 \\
\hline $\begin{array}{l}\text { There has been an increase or decrease in my appetite } \\
\text { compared to before (yes) }\end{array}$ & 21 & 65.6 & 10 & 47.6 & 31 & 58.5 & 0,310 \\
\hline $\begin{array}{l}\text { There has been an increase in my complaints that } \\
\text { caused me to apply to the child psychiatry clinic (yes) }\end{array}$ & 13 & 40.6 & 4 & 19.0 & 17 & 32.1 & 0,179 \\
\hline
\end{tabular}

Two group comparisons are analyzed by Chi Square Test. None of the comparisons revealed statistical significance (p>0.05)

Concern about being infected by Covid-19

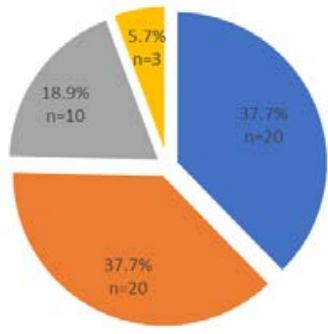

- not worried "slightly worried "moderately worried " too much worried

Figure 2. The adolescents' worries about being infected by the Covid-19

Concern about his/her relatives being infected by Covid-19

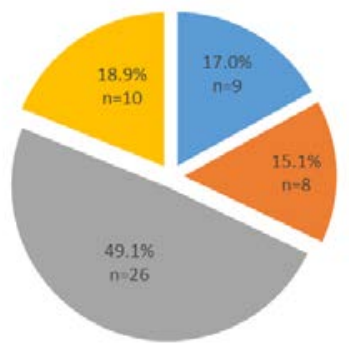

- not worried as sightly worried "moderately wortied " toomuch worried

Figure 3. The adolescents' worries about his/her relatives being infected by the Covid-19
Table 4. Total SCARED and CDI scores according to various parameters

\begin{tabular}{|c|c|c|c|c|c|c|}
\hline & \multicolumn{3}{|c|}{ Total SCARED } & \multicolumn{3}{|l|}{ Total CDI } \\
\hline & $\begin{array}{l}\text { Median- } \\
\text { IQR }\end{array}$ & $\mathbf{z}$ & $\mathbf{p}$ & $\begin{array}{l}\text { Median- } \\
\text { IQR }\end{array}$ & $z$ & p \\
\hline \multicolumn{7}{|l|}{$\begin{array}{l}\text { Is Covid-19 infection a serious } \\
\text { health threat? }\end{array}$} \\
\hline Yes & $32-19$ & \multirow{2}{*}{-2.519} & \multirow{2}{*}{$0.012^{*}$} & $15-12$ & \multirow{2}{*}{-1.429} & \multirow{2}{*}{0.153} \\
\hline $\mathrm{No}^{\mathrm{a}}$ & $27-17.5$ & & & $12.5-11$ & & \\
\hline \multicolumn{7}{|l|}{$\begin{array}{l}\text { Do you obey the Covid-19 pre- } \\
\text { ventive measures? }\end{array}$} \\
\hline Yes & $\begin{array}{l}29.5- \\
20.2\end{array}$ & \multirow[t]{2}{*}{-0.164} & \multirow[t]{2}{*}{0.870} & $\begin{array}{l}13.5- \\
13.7\end{array}$ & \multirow[t]{2}{*}{-0.701} & \multirow[t]{2}{*}{0.483} \\
\hline No & $32-20$ & & & $14-11.5$ & & \\
\hline \multicolumn{7}{|l|}{$\begin{array}{l}\text { Did your application complaint } \\
\text { increase during the pandemic? }\end{array}$} \\
\hline Yes & $32-17$ & \multirow{2}{*}{-1.478} & \multirow{2}{*}{0.139} & $21-13.5$ & \multirow{2}{*}{-2.214} & \multirow{2}{*}{$0.027^{*}$} \\
\hline No & $28.5-22$ & & & $13-10$ & & \\
\hline
\end{tabular}

SCARED: Screen for Child Anxiety Related Emotional Disorders, CDI: The

Children's Depression Inventory, IQR: Inter-quartile range, *statistical sig nificance is accepted at $p<0.05$ (Mann-Whitney $U$ Test), ${ }^{a}$ The participants' answers including both "Covid-19 is a partial health threat" and "Covid-19 is not a health threat" are accepted under the "No" heading.

\section{Discussion}

In the present study, a clinical sample of adolescents selfdefined their Covid-19 infection perception and their compliance to the recommended precautions in the pandemic's early days. The study results showed that about two-thirds of the adolescents perceived the infection as a severe health threat. The participants were more concerned about their relatives getting infected by the virus than self-illness. Sixty percent stated that they were adhering to the Covid-19 preventive measures. Girls were using immune system supportive products more than boys, and they seemed to be psychologically influenced by the pandemic more than boys. However, there was no statistical difference in this regard. Similarly, the participants' 
diagnostic group did not affect the pandemic-related exacerbation in psychological distress, as well as the compliance to the measures. The adolescents who perceived the Covid-19 as a serious health threat reported higher anxiety scores. Also, the ones who stated aggravation in application complaints in the pandemic had higher depression scores.

Sixty-six percent of the sample stated that they perceived covid-19 infection as a serious health threat, $94.3 \%$ said they were adequately informed about the infection, and 92.5\% stated that the preventive measures would be effective in the control of the spread of the virus. A study conducted with a community sample of adolescents in Italy reported that $36 \%$ of the sample believed that contracting the virus could be serious or very serious. In the same study, $74.6 \%$ of the respondents reported having confidence in the information they received on the disease (29). Our participants seem to take the infection more seriously than Italian peers; they seem to have a better sense of adequacy in terms of reaching information. Authors of another study conducted in Jordan commented that Jordanian adolescents had a good level of knowledge regarding COVID-19. They generally had positive attitudes toward the country's curfew and other protective measures (30). We also showed that adolescents in our sample have positive attitudes and a high confidence level for that the preventive measures will be effective in controlling pandemics.

One of the study's main aims was to search the adolescents' compliance to preventive measures at the outbreak of the pandemic. Accordingly, we found that $60.4 \%$ stated they were adhering to all warnings about the covid-19 pandemic, and $39.6 \%$ were not wholly adhering. Regarding hygiene behaviors, most of them were found to follow the recommendations. About $80 \%$ of the adolescents were washing their hands six or more times a day. Half of them were using hand disinfectant, $90.6 \%$ were paying attention to closing their mouth and nose while sneezing/coughing, $83 \%$ were regularly ventilating their environment, and $94.3 \%$ were paying attention to social distance. However, the ratio of those wearing a face mask every time out of home was $34 \%$, which was a low ratio. A community-based study conducted with college students in America found that mask use in public at all times was $50.8 \%$, and the compliance to other hygiene behaviors was greater, alike to our results (31). An adult study from America also reported similar ratios; $50 \%$ were wearing face masks, $88 \%$ were regularly washing hands, and $91 \%$ covered the mouth and nose while sneezing, and $87 \%$ were paying attention to social distance (11). A study conducted with children and adolescents in India reported far less compliance to preventive measures related to the Covid-19 pandemic. Only $7.4 \%$ were found to be compliant with all requirements, and $17.3 \%$ were found to be obedient to community protective measures (32). Cultural, methodological, sample characteristics related, and pandemic severity associated differences between the studies may be the reason for significant variations. Additively, we did not find any difference in terms of compliance to preventive measures between boys and girls. Nivette et al. (2020) reported higher noncompliance among young male adults (10). Similarly, Park et al. (2020) found that females were more adherent to preventive measures. Overall, we can comment that clinical samples of adolescents seem to be no worse than community samples in adherence to recommendations. People may be more non-compliant to facemask wearing in comparison to other preventive measures.

The rate of adolescents who stated that they were regularly eating (paying attention to regular nutrition) to keep their immune system strong was $64 \%$. Those who were using immune system supportive products was $79 \%$, and those who stated that they took care to regular sleep was $66 \%$. We found a statistically significant difference between girls and boys only in the use of supportive products. A two-phase online study conducted in Poland in the first and second waves of the pandemic reported that during the Covid-19, the interest in immune-related compounds and pro-healthy foods and their consumption increased. The dietary supplements were used by $48 \%$ in March and $79 \%$ in November 2020, and the authors reported that women used them more (33). We consider that most of the adolescents in our study take care of their physical health. Adolescent girls are more inclined to use immune system supportive products such as vitamin-mineral pills and herbal products.

We also asked the adolescents about the fear of getting infected. Expectedly, we found that they were more concerned about the health of loved ones than personal health. The ones who stated that he/she was moderately anxious about the health of relatives was $68 \%$ of the sample, while those who gave the same answer for themselves were $24.6 \%$. Girls and boys were not different regarding the Covid-19 fear. In an online study conducted in March 2020 in 28 different countries with a sample aged 16 to 80 years, it was reported that $46.2 \%$ of the participants were concerned about the health of others. However, only $11 \%$ were worried about personal health. Gender did not impact the Covid-19 fear (34). Another study conducted in America with adults reported anxiety for self-infection vs. loved ones' infection $56.8 \%$ vs. $61.3 \%$. The study found females were more stressed than males (11). Cultural variations, the severity of the pandemic's spread in the study country, and the participants' age group may be related to differences among studies. Nevertheless, our adolescent sample seems quite anxious about the hazards of Covid19 , especially for the loved ones. This situation is probably because our sample is a clinical sample with higher anxiety levels than the community. Adolescents are experiencing a new period of insecurity; clinical samples are more vulnerable. They experience anxiety due to perceived risks of the infection for the loved ones and personal health. 
In the pandemic period, the measures such as isolation and contact restrictions can negatively impact the mental health of children and adolescents significantly. If the adolescent has a previous mental disorder, the risk for experiencing psychological problems during the pandemic is more significant (16). The researchers reported that the adolescents who had previous mental disorders experienced worsening in their mental health in pandemic time $(35,36)$. Our study found that nearly a third $(32.1 \%)$ of the adolescents reported an increase in the severity of their complaints that caused them to refer to child psychiatry clinic. About forty to fifty percent stated that they were more anxious, unhappy, or irritable than before. Similarly, a substantial proportion of them (37.7\%) reported increased concentration problems, and more than half of the sample stated their sleep and appetite were influenced during the pandemic. Thus, our findings were in line with our expectations and the literature. It seems as if the Covid-19 pandemic led to a worsening in existing psychological symptoms in adolescents from a clinical sample with pre-existing vulnerabilities. Literature data support that the female gender is more prone to the pandemic's psychological influences $(37,38)$. In our study, the variation of psychological distress in the Covid-19 pandemic did not differ according to gender. Together with this, a more significant proportion of girls reported an increase in psychological symptoms than boys. Our relatively small sample size may be a reason for the statistical indifference. We also add that the adolescents in our sample had very high anxiety and relatively high depression scores. Birmaher et al. (1997) reported a mean SCARED score of $26.76 \pm 14.68$ in a clinical sample of anxiety cases less than ours (27). The high anxiety scores are probably a reflection of increased stress during the outbreak of a pandemic.

We also searched if the adolescent's diagnostic status impacted the compliance to preventive measures the exacerbation in referral complaints. In this regard, we found no statistical difference between the diagnostic groups. Although there have been studies conducted to investigate the impact of Covid-19 in special diagnosis groups, we could not reach a study that compared different diagnostic groups with each other $(36,39)$. Nivette et al. (2020) reported that antisocial pattern is related with noncompliance to Covid-19 precautions (10). This topic can be better evaluated with larger samples, including a large variety of diagnostic groups.

Similarly, there was no difference in anxiety or depression scores between the compliant and non-compliant adolescents. Besides, we showed that the adolescents who perceived Covid-19 as a serious health threat had higher anxiety scores, and the ones who defined aggravation in referral symptoms had higher depression scores. The previous stress level may impact the coping skills and how the person interprets stressful life events and affects his/her current mental health (17-20).

The current study has some limitations that should be mentioned. Firstly, we collected data only from the adolescents themselves. We do not have any other source, such as parents. Secondly, the findings can not be generalized since our participants were selected only from a clinical sample. In future studies, assessing both clinical and community samples at the same section and comparing the groups with each other may provide more detailed and generalizable information. Thirdly, our sample size was relatively small. Some insignificant findings might have reached a statistical significance level if our sample size was larger. Fourthly we collected data on the emergence of the pandemic in our country. In the following months, adolescents' perception of the infection and its health hazards might have changed. Also, the psychological distress they experienced might have changed. In time, people may get used to the pandemic's limitations, and the psychological distress may decrease, leading to increased compliance. On the other side, the inverse also can occur. Extended constraints may cause the people to get exhausted, the compliance may worsen, negative mental influences may strengthen. Nevertheless, our study results provide a picture from a selected particular time; and we believe that they are important to reflect the adolescents' first reactions.

Conclusively, we here showed that the adolescents who had child psychiatry referral in the pre-pandemic period had higher levels of psychiatric complaints than the general community complied with Covid-19 precautions moderate-good level. They were inclined to be worried for their relatives more than they were concerned for themselves. The diagnostic status or their anxiety or depression level were not found to influence their compliance. However, the ones who experienced aggravation in his/her application complaints were the ones with higher levels of depression scores. The ones who perceived the disease as a severe health threat were the ones with higher anxiety scores. These findings may suggest that even the adolescent is under psychological stress and prone to adolescent stage-specific risky behaviors; he/she tries to adhere to the precautions. With this, his/her anxiety level may affect the perception of the disease severity and his/her depression level may affect the stress he/she experienced during the pandemic. The child and adolescent mental health workers should keep these findings in mind to help the adolescents more effectively. Future studies with larger samples are needed to robust these results. Specifically, larger clinical samples are required to assess the diagnostic vulnerability.

Ethical Approval: Pamukkale University Ethics Committee (Date:16/04/2020 No: 60116787-020/26616) and Turkish Republic Ministry of Health approved the study.

Author Contributions:

Concept: $O ̈ B, B K B$

Literature Review: $O ̈ B, B K B, F O ̈$

Design : ÖB, $B K B, F \ddot{O}$

Data acquisition: $F O ̈, O ̈ B, B K B$ 
Analysis and interpretation: $\ddot{O} B, B K B, F \ddot{ }$
Writing manuscript: $\ddot{O} B, B K B, F \ddot{O}$
Critical revision of manuscript: $O ̈ B, B K B, F O ̈$

Critical revision of manuscript: $\ddot{O B}, B K B, F O \ddot{O}$

Conflict of Interest: The authors have no conflicts of interest to declare.

Financial Disclosure: Authors declared no financial support.

\section{References}

1. Zhu N, Zhang D, Wang W, Li X, Yang B, Song J, et al. A novel coronavirus from patients with pneumonia in China, 2019. N Engl J Med. 2020;382(8):727-33.

2. Cucinotta $D$, Vanelli $M$. WHO declares COVID-19 a pandemic. Acta Biomed. 2020;91(1):157-60.

3. Şeker M, Özer A, Tosun Z, Korkut C, Doğrul M. COVID-19 küresel salgın değerlendirme raporu. Türkiye Bilimler Akademisi Yayınları, TÜBA Raporları. 2020;34. Available from http://www.tuba.gov.tr/files/images/2020/kovidraporu/Covid-19\%20Raporu-Final\%2B.pdf. (access Jan 19, 2021)

4. World Health Organization. Coronavirus disease (COVID2019) situation reports. https://www.who.int/emergencies/diseases/novel-coronavirus-2019/situation-reports. (access Jan 16, 2021)

5. Pradhan D, Biswasroy P, Ghosh G, Rath G. A review of current interventions for COVID-19 prevention. Arch Med Res. 2020;51(5):363-74.

6. Demirbilek $Y$, Pehlivantürk G, Özgüler ZÖ, Alp Meşe E. COVID-19 outbreak control, example of ministry of health of Turkey. Turk J Med Sci. 2020;50(3):489-94.

7. Erikson EH. Identity and life Cycle. New York: Norton; 1980.

8. Dayan J, Bernard A, Olliac B, Mailhes AS, Kermarrec S. Adolescent brain development, risk taking and vulnerability to addiction. J Physiol Paris. 2010;104(5):279-86.

9. Blos $P$. The second individuation process of adolescence. Psychoanal Study Child. 1967;22:162-86.

10. Nivette A, Ribeaud D, Murray A, Steinhoff A, Bechtiger L, Hepp $U$, et al. Noncompliance with covid-19-related public health measures among young adults in Switzerland: insights from a longitudinal cohort study. Soc Sci Med. 2021;268:e113370.

11. Park $C L$, Russell $B S$, Fendrich $M$, Finkelstein-Fox $L$, Hutchison M, Becker J. Americans' COVID-19 stress, coping, and adherence to CDC guidelines. J Gen Intern Med. 2020;35(8):2296-303.

12. CDC COVID-19 Response Team. Severe outcomes among patients with coronavirus disease 2019 (COVID-19) United States, February 12-March 16, 2020 MMWR Morb Mortal Wkly Rep. 2020;69(12):343-46.

13. Petersen AC, Hamburg BA. Adolescence: A developmental approach to problems and psychopathology. Behav Ther. 1986;17(5):480-99.

14. Costello EJ, Mustillo S, Erkanli A, Keeler G, Angold A. Prevalence and development of psychiatric disorders in childhood and adolescence. Arch Gen Psychiatry. 2003;60(8):837-44.

15. Newman DL, Moffitt TE, Caspi A, Magdol L, Silva PA, Stanton WR. Psychiatric disorder in a birth cohort of young adults: prevalence, comorbidity, clinical significance, and new case incidence from ages 11 to 21. J Consult Clin Psychol. 1996;64(3):552-62.

16. Fegert JM, Vitiello B, Plener PI, Clemens V. Challenges and burden of the coronavirus 2019 (COVID-19) pandemic for child and adolescent mental health: a narrative review to highlight clinical and research needs in the acute phase and the long return to normality. Child Adolesc Psychiatry Ment Health. 2020;14:e20.

17. Fluori E, Tzavidis N, Kallis C. Adverse life events, area socioeconomic disadvantage, and psychopathology and resilience in young children: the importance of risk factors' accumulation and protective factors' specificity. Eur Child Adolesc Psychiatry. 2009;19(6):535-46.

18. Salleh M. Life event, stress and illness. Malays J Med Sci. 2009;15(4):9-18.

19. Schneiderman N, Ironson G, Siegel SD. Stress and health: psychological, behavioral, and biological determinants. Annu Rev Clin Psychol. 2005;1(1):607-28.

20. Compas BE, Orosan PG, Grant KE. Adolescent stress and coping: implications for psychopathology during adolescence J Adolesc. 1993;16(3):331-49.

21. Hartman $\mathrm{CA}$, Rommelse $\mathrm{N}$, van der Klugt $\mathrm{CL}$, Wanders $\mathrm{RBK}$, Timmerman ME. Stress exposure and the course of ADHD from childhood to young adulthood: comorbid severe emotion dysregulation or mood and anxiety problems. J Clin Med. 2019;8(11):1824-39.

22. Kendler KS, Thornton LM, Prescott CA. Gender differences in the rates of exposure to stressful life events and sensitivity to their depressogenic effects. Am J Psychiatry. 2001;58(4):587-93.

23. Bouma EMC, Ormel J, Verhulst FC, Oldehinkel AJ. Stressful life events and depressive problems in early adolescent boys and girls: the influence of parental depression, temperament and family environment. J Affect Disord. 2008;105(1-3):185-93.

24. Wong $\mathrm{CY}$, Tang CS. Practice of habitual and volitional health behaviors to prevent severe acute respiratory syndrome among Chinese adolescents in Hong Kong. J Adolesc Health. 2005;36(3):193-200.

25. Kovacs M. The Children's Depression Inventory (CDI). Psychopharmacol Bull. 1985;21(4):995-98.

26. Öy B. Children's Depression Inventory: validity and reliability study. Turkish J Psychiatry. 1991;2:132-36.

27. Birmaher B, Khetarpal S, Brent D, Cully M, Balach L, Kaufman J, et al. The Screen for Child Anxiety Related Emotional Disorders (SCARED): scale construction and psychometric characteristics. J Am Acad Child Adolesc Psychiatry. 1997;36(7):545-53.

28. Karaceylan Cakmakci F. Reliability and validity of SCARED in Turkish children (PhD dissertation). Kocaeli: Kocaeli University; 2005.

29. Commodari E, La Rosa VL. Adolescents in quarantine during COVID-19 pandemic in Italy: perceived health risk, beliefs, psychological experiences and expectations for the future. Front Psychol. 2020;11:e559951.

30. Dardas LA, Khalaf I, Nabolsi M, Nassar O, Halasa S. Developing an understanding of adolescents' knowledge, attitudes, and practices toward COVID-19. J Sch Nurs. 2020;36(6):430-41.

31. Cohen AK, Hoyt LT, Dull B. A descriptive study of coronavirus disease 2019 related experiences and perspectives of a national sample of college students in spring. J Adolesc Health. 2020;67(3):369-75.

32. Saurabh K, Ranjan S. Compliance and psychological impact of quarantine in children and adolescents due to Covid-19 pandemic. Indian J Pediatr. 2020;87(7):532-36.

33. Hamulka J, Jeruszka-Bielak M, Gornicka M, Drywien ME, 
Zielinska-Pukos MA. Dietary supplements during COVID-19 outbreak. Results of Google Trends Analysis Supported by PLifeCOVID-19 Online Studies. Nutrients. 2021;13(1):5471.

34. Mertens G, Gerritsen L, Duijndam S, Salemink E, Engelhard I. Fear of the coronavirus (COVID-19): predictors in an online study conducted in March 2020. J Anxiety Disord. 2020;74:e102258.

35. Youngminds, 2020, March. Coronavirus: Impact on young people with mental health needs. Available from: https://youngminds.org.uk/media/3708/coronavirusreport_march2020.pdf. (access Jan 19, 2021)

36. Guessoum SB, Lachal J, Radjack R, Carretier E, Minassian S, Benoit L, Moro MR. Adolescent psychiatric disorders during the covid-19 pandemic and lockdown. Psychiatry Res. 2020;291:e113264.

37. Zhou SJ, Zhang LG, Wang LL, Guo ZC, Wang JQ, Chen JC, et al. Prevalence and sociodemographic correlates of psychological health problems in Chinese adolescents during the outbreak of COVID-19. Eur Child Adolesc Psychiatry. 2020;29:749-58.

38. Liu N, Zhang F, Wei C, Jia Y, Shang Z, Sun L, et al. Prevalence and predictors of PTSS during COVID-19 outbreak in China hardest-hit areas: gender differences matter Psychiatry Res. 2020;287: e112921.

39. Singh S, Roy D, Sinha K, Parveen S, Sharma G, Joshi G. Impact of COVID-19 and lockdown on mental health of children and adolescents: a narrative review with recommendations. Psychiatry Res. 2020;20:e113429. 